Упровадження системи соціалізації студентської молоді педагогічного університету в позанавчальній діяльності засобами народного декоративно-ужиткового мистецтва

\title{
УПРОВАДЖЕННЯ СИСТЕМИ СОЩАЛІЗАЦІЇ СТУДЕНТСЬКОЇ МОЛОДІ ПЕДАГОГІЧНОГО УНІВЕРСИТЕТУ В ПОЗАНАВЧАЛЬНІЙ ДІЯЛЬНОСТІ ЗАСОБАМИ НАРОДНОГО ДЕКОРАТИВНО- УЖИТКОВОГО МИСТЕЦТВА
}

\author{
Світлана Саяпіна \\ доктор педагогічних наук, \\ доцент, професор кафедри педагогіки вищої школи \\ ДВНЗ «Донбаський державний педагогічний університет», \\ м. Слов'янськ, Україна \\ ORCID ID 0000-0001-5808-7020 \\ Svetlana.sayapina65@gmail.com \\ Вікторія Мухіна \\ кандидат педагогічних наук, \\ старший викладач кафедри психології \\ ДВНЗ «Донбаський державний педагогічний університет», \\ м. Слов'янськ, Україна \\ ORCID ID 0000-0002-7248-672X \\ viktoriy.m3@gmail.com
}

\begin{abstract}
Анотація. Статтю присвячено проблемі соціалізації студентської молоді педагогічного університету в позанавчальній діяльності засобами народного декоративно-ужиткового мистецтва. Теоретично обгрунтовано систему соціалізації студентської молоді педагогічного університету в позанавчальній діяльності засобами народного декоративно-ужиткового мистецтва, яка включає цільовий, концептуальний, суб'єктний, змістово-технологічний, діагностико-результативний блоки; представлено характеристику кожного 3 компонентів системи. Доведено ефективність запропонованої системи соціалізації студентської молоді педагогічного університету в позанавчальній діяльності засобами народного декоративноужиткового мистецтва та доцільність ï впровадження в практику діяльності педагогічних закладів вищої освіти. Розроблено, теоретично обгрунтовано та експериментально перевірено систему соціалізації студентської молоді педагогічного університету в позанавчальній діяльності засобами народного декоративно-ужиткового мистецтва, яка включає цільовий, концептуальний, суб' єктний, змістово-технологічний, діагностико-результативний блоки.
\end{abstract}

Ключові слова: студентська молодь; позанавчальна діяльність; експеримент; декоративно-ужиткове мистецтво; соціалізація; педагогічний університет.

Постановка проблеми в загальному вигляді. Сучасний етап розвитку незалежної України характеризується стратегічним курсом на оновлення всіх сфер суспільного життя, зокрема освіти. Успішність процесу соціалізації молоді як особливої демографічної групи визначено нині важливим чинником інтеграції закладів освіти України до європейського освітнього простору. Саме тому до

Професіоналізм педагога: теоретичні й методичні аспекти. - Вип. 14 (Ч. 1). - Слов’янськ, 2021. 
Упровадження системи соціалізації студентської молоді педагогічного університету в позанавчальній діяльності засобами народного декоративно-ужиткового мистецтва

пріоритетних завдань теорії та практики соціальної педагогіки належить обгрунтування значення освітнього й культурного складників у загальному соціалізаційному процесі молодої людини, створення та реалізація сприятливих для цього умов освітнього середовища.

Необхідність розв'язання цих завдань підтверджена положеннями нормативно-законодавчих актів із питань соціалізації молодого покоління: Законами України: «Про вищу освіту» (2014 р., із змінами та доповненнями 2017 р.), «Про сприяння соціальному становленню та розвитку молоді в Україні» (2016 р.); Концепцією державної етнонаціональної політики України (2018 р.), Стратегією національно-патріотичного виховання дітей і молоді на 2016 2020 рр., Концепцією національного виховання студентської молоді тощо.

3 огляду на це особливого значення набуває організація соціалізації студентської молоді педагогічного університету в позанавчальній діяльності засобами народного декоративно-ужиткового мистецтва, яке відрізняється різноманітністю, виразністю, оригінальністю, вбирає емпіричні знання й культуру багатьох попередніх поколінь, характеризує зміст ціннісних орієнтацій народу й може стати інформаційним джерелом виховання та навчання молоді.

Аналіз останніх досліджень і публікацій. Проблему організації позанавчальної або позааудиторної роботи в умовах закладу вищої освіти розглядали такі сучасні вітчизняні науковці, як А. Брусенко, С. Іванчикова, О. Палеха, С. Пранова, І. Ратинська, В. Тернопільська, В. Тимошенко, Н. Шелест та ін. Комплекс праць (Ю. Баранецька, Г. Бучківська, В. Власова, Л. Гарбузенко, С. Лавриненко, Ж. Сироткіна, В. Смікал, М. Томашівська, I. Ушакова, Л. Фірсова, В. Чупіна, В. Швирка та ін.) присвячено використанню мистецтва як засобу особистісного розвитку молодої людини.

Проте, незважаючи на грунтовні наукові дослідження за окресленими напрямами, проблема соціалізації студентської молоді педагогічного університету в позанавчальній діяльності засобами народного декоративноужиткового мистецтва залишається не дослідженою.

Формулювання цілей статті (постановка завдання). Мета статті полягає у висвітленні специфіки реалізації системи соціалізації студентської молоді педагогічного університету в позанавчальній діяльності засобами народного декоративно-ужиткового мистецтва.

Результати дослідження. Реалізація системи соціалізації студентської молоді педагогічного університету в позанавчальній діяльності засобами народного декоративно-ужиткового мистецтва здійснювалася крізь призму ї компонента «Зміст», що включає три складники: 1) теоретичну підготовку 
студентів; 2) практичну підготовку студентів; 3) методичну підготовку студентів. При цьому зауважимо, що експериментальна соціально-педагогічна робота враховувала всі інші компоненти та елементи цієї системи.

У перший блок «Теоретична підготовка студентів» входять знання про процес створення, розвитку і сприйняття художнього образу, різні види вітчизняного декоративно-ужиткового мистецтва; історію й розвиток народних промислів свого регіону та України, їх основні види; сутність і класифікацію народного мистецтва; технологію виготовлення виробів народної творчості; загальну будову і принципи роботи верстатів, пристосувань, що застосовуються при виготовленні виробів декоративно-ужиткового мистецтва.

На формувальному етапі експерименту ми виходили 3 того, що для повноцінної соціалізації студентської молоді педагогічного університету в позанавчальній діяльності засобами народного декоративно-ужиткового мистецтва необхідно наповнити відповідною інформацією зміст теоретичної підготовки майбутніх учителів такими способами:

1) цілісне надання систематизованої інформації в межах факультативу «Народне декоративно-ужиткове мистецтво»;

2) включення елементів теорії в зміст діяльності студентських наукових гуртків / проблемних груп, що розглядають проблематику впливу мистецтва на розвиток особистості;

3) фрагментоване надання теоретичних знань про народне декоративноужиткове мистецтво в межах реалізації інших форм позанавчальної роботи.

Так, факультатив «Народне декоративно-ужиткове мистецтво» студенти вивчали протягом року, він включав блок лекційних та практичних занять із вивчення основ декоративно-ужиткової творчості. Зокрема, студенти на лекційних і практичних заняттях за темою «Народне мистецтво як прояв народної творчості» отримували теоретичні знання про художню культуру; роль мистецтва для суспільства й розвитку особистості; сутність і види народного мистецтва; народне декоративно-ужиткове мистецтво, його регіональні відмінності та особливості.

На факультативних заняттях 3 теми «Становлення та розвиток народного декоративно-ужиткового мистецтва» здобувачі знайомилися 3 історію та основними етапами розвитку українського народного декоративно-ужиткового мистецтва; центрами розвитку народних художніх промислів і ремесел у різних регіонах України.

Морфологічний аналіз видів декоративно-ужиткового мистецтва (ткацтва, килимарства, вишивки, витинанки, аплікації, кераміки, писанкарства, 
художнього розпису тощо) було представлено при висвітленні матеріалу наступної теми факультативу «Види декоративно-ужиткового мистецтва».

Вивчаючи на факультативних заняттях видове різноманіття українського народного декоративно-ужиткового мистецтва, студенти аналізували їх за п’ятьма сутнісними характеристиками (декоративна і прикладна спрямованість, сюжетна своєрідність, специфічне колірне рішення, мовна своєрідність і технологічна відтворюваність), властивими кожному виду народної творчості, але які відрізняються своєю специфічністю, наприклад, студенти, вивчаючи традиційні народні художні промисли: українську глиняну іграшку (на прикладі Опішнянської іграшки - Полтавщина) і українську дерев'яну іграшку цього ж регіону (на прикладі Сорочинської іграшки - Полтавщина), порівнюють їх між собою за п'ятьма характеристиками, виділяють відмінні риси.

Отже, завдяки глибокому аналізу сутнісних характеристик кожного виду традиційного й регіонального декоративно-ужиткового мистецтва майбутні вчителі пізнавали всі тонкощі майстерності й таємниці народних умільців, що в подальшому сприятиме більш ефективному становленню їх як творчих особистостей та педагогів.

Аналіз проведених у ході формувального етапу експерименту занять виявляє в якості ефективних відеозаняття i «майстер-класи онлайн», які дозволяють проаналізувати діяльність майстра, його творчі роботи, процес художньої обробки матеріалу та його технологію. Відеозаписи дають можливість познайомитися 3 творчістю майстрів килимарства, ковальської справи, кераміки, вишивки з міст і сіл усієї України.

Продовжуючи висвітлення здійснених на формувальному етапі експерименту способів надання студентам теоретичної інформації про народне декоративно-ужиткове мистецтво, розглянемо специфіку діяльності за цим напрямом наукових гуртків або студентських проблемних груп.

Вивчення нормативних положень закладів вищої освіти, які стали експериментальною базою нашого дослідження (Донбаський державний педагогічний університет (м. Слов'янськ), Полтавський національний педагогічний університет імені $\quad$ В.Г. Короленка), дало можливість сформулювати сутність понять «студентський науковий гурток» (об'єднання здобувачів вищої освіти при кафедрі університету, що формується за напрямом наукової діяльності кафедри відповідно до затверджених тематичних планів роботи кафедри) та «проблемна група» (об’єднання здобувачів вищої освіти при кафедрі університету з метою дослідження конкретно визначеної наукової проблеми, пов'язаної з напрямом наукових досліджень кафедри).

() ДВНЗ «Донбаський державний педагогічний університет» 
За нашої ініціативи в зазначених вище університетах були створені проблемні студентські групи «Теорія і практика використання декоративноужиткового мистецтва в закладах освіти», діяльність яких протягом двох років експериментальної роботи сприяла залученню студентів до участі внаукових заходах: 12 студентів узяли участь у XVII Міжнародній студентській науковопрактичній інтернет-конференції «Мова. Освіта. Культура: Інтеграційні тенденції в сучасному світі» (2018 р.); 5 здобувачів - у науково-практичній конференції студентів і молодих учених «Молодь України в контексті міжкультурної комунікації» (2019 р.); 7 студентів - у Міжнародній науковопрактичній конференції студентів, аспірантів та молодих науковців «Регіон 2019: суспільно-географічні аспекти» (2019 р.); 8 здобувачів - у Міжнародній науково-технічній інтернет-конференції «Новітні технології в освіті, науці та виробництві» (2020р.).

За 3 роки експерименту в різноманітних семінарах і круглих столах («Витинанка як вид народного декоративно-ужиткового мистецтва», «Вишивка - надбання українського народу», «Нетрадиційні техніки в народному декоративно-ужитковому мистецтві», «Народне мистецтво західних областей України», «Регіональні особливості декоративно-ужиткового мистецтва» та ін.) узяло участь близько 200 здобувачів вищої освіти Донбаського державного педагогічного університету та Полтавського національного педагогічного університету імені В. Г. Короленка.

Перебування здобувачів у проблемних студентських групах «Теорія i практика використання декоративно- ужиткового мистецтва в закладах освіти» сприяла не лише більш глибокому осмисленню ролі декоративно-ужиткового мистецтва, але й їх науковому зростанню: формуванню наукового світогляду, інтересу до наукової творчості, навичок роботи в наукових колективах; оволодінню ними методологією та методами наукового дослідження; розвитку творчого мислення, наукової самостійності тощо.

Дослідно-експериментальна робота в рамках цього дослідження передбачала не тільки ознайомлення студентів педагогічного університету 3 теоретичними засадами декоративно-ужиткового мистецтва, але також i практичну підготовку з формування в майбутніх учителів конкретних умінь i навичок у роботі з творами декоративно-ужиткового мистецтва. У дидактиці, як відомо, під уміннями розуміють сукупність послідовних дій, частина з яких може бути автоматизована (навички), заснованих на теоретичних знаннях i спрямованих на вирішення завдань розвитку гармонійної особистості (Тернопільська, 2003). 
На нашу думку, при цілісному описі вмінь, актуальних для цього дослідження, необхідно, перш за все, виходити з сутнісних характеристик декоративно-ужиткового мистецтва, до яких, як було сказано в першому розділі дисертації, нами віднесені: а) естетична і прикладна спрямованість; б) сюжетна своєрідність; в) специфічне колірне рішення; г) мовна своєрідність і д) технологічна відтворюваність.

Аналіз процесу виготовлення творів декоративно- ужиткового мистецтва, наукових робіт, що описують його, методичних рекомендацій із навчання дітей декоративно- ужиткової творчості дозволив за першою ознакою «естетична i прикладна спрямованість» виокремити такі вміння: виділяти з об'єктів реальної дійсності вироби народного мистецтва, що мають естетичну і прикладну цінність; аналізувати зразки декоративно-ужиткового мистецтва 3 погляду їх естетичної та прикладної спрямованості; відрізняти твори традиційної народної творчості та твори свого краю за естетичною та прикладною спрямованістю; застосовувати знання про художньо-естетичні достоїнства і складові елементи виробів декоративно-ужиткового мистецтва в професійній діяльності.

3 другою відмінною рисою творів декоративно-ужиткового мистецтва нами поєднаний такий склад основних умінь: визначати вид орнаменту (геометричний, рослинний, зооморфний, антропоморфний, комбінований); розрізняти традиційні схеми побудови орнаменту (лінійний, сітчастий, замкнутий); створювати орнамент, притаманний виробам декоративноужиткового мистецтва України і свого регіону; відрізняти один вид декоративноужиткового мистецтва від іншого за орнаментальністю, казковістю, ступенем взаємозв’язку з природою та ін. (Бучівська, 2019; Власова, 2019; Гарбузенко, 2016).

За третьою сутнісною характеристикою виробів декоративно-ужиткового мистецтва ми виокремлюємо такі вміння: використовувати колір як засіб художньої виразності у створенні образу декоративної речі; застосовувати при створенні твору декоративно-ужиткового мистецтва різні види декоративного розпису; розрізняти твори народних майстрів, у яких відображені художні традиції; визначати за колористичним вирішенням художніх речей у якому центрі народної творчості України створені вироби.

За ознакою творів декоративно-ужиткового мистецтва «мовна своєрідність» ми пропонуємо такий склад умінь: стилізувати реальні природні форми в декоративні; розуміти художньо-виразні особливості мови декоративно-ужиткового мистецтва; визначати символічне значення художнього образу творів традиційного й регіонального декоративно-ужиткового мистецтва; 
Упровадження системи соціалізації студентської молоді педагогічного університету в позанавчальній діяльності засобами народного декоративно-ужиткового мистецтва

використовувати лінію, ритм, силует, пропорції, композицію як засоби художньої виразності у створенні образу декоративної речі.

За художньою відтворюваністю вміння бувають щодо: застосовування основних матеріалів для створення конкретних видів декоративно-ужиткового мистецтва; вибору й використання найбільш виразних прийомів і засобів для створення задуманого художнього образу у виробі декоративно-ужиткового мистецтва; проєктування зразків декоративно-ужиткового мистецтва; використання різних технологій художньої обробки матеріалів; визначення за технологією обробки матеріалу, у якому центрі народної творчості України створені вироби; виконання творів декоративно-ужиткового мистецтва свого краю (Лавриченко, 2005; Сироткіна, 2006).

Отже, реалізація системи соціалізації студентської молоді педагогічного університету в позанавчальній діяльності засобами народного декоративноужиткового мистецтва спрямовувалася, у першу чергу, на формування в студентів саме перерахованих вище вмінь.

При оволодінні студентами експериментальних педагогічних університетів уміннями декоративно-ужиткової творчості в дослідно-практичній роботі використано різноманітні форми і методи.

Ми рекомендували суб’єктам процесу соціалізації студентської молоді педагогічного університету в позанавчальній діяльності засобами народного декоративно-ужиткового мистецтва (викладачі 3ВО, які спеціалізуються на декоративно-ужитковому мистецтві; народні майстри; керівники гуртків декоративно-ужиткової творчості в позашкільних закладах; представники краєзнавчих музеїв та ін.) використовувати на практиці такі пояснювальноілюстративні методи, як: метод ілюстрацій зразків декоративно-ужиткового мистецтва; метод демонстрацій виконання творів декоративно-ужиткової творчості; метод розповіді про вироби декоративно-ужиткового мистецтва.

Застосування цих методів забезпечувало наочну демонстрацію студентам послідовності складання різного орнаменту; освоєння майбутніми вчителями алгоритму створення творів декоративно-ужиткового мистецтва; визначення ними за колористичним вирішенням художніх речей, у якому центрі народної творчості України ці вироби створені; компетентність аналізувати зразки декоративно-ужиткового мистецтва 3 погляду їх естетичної та прикладної спрямованості.

Застосування викладачами-майстрами в роботі зі студентами методу композиційних варіацій сприяв розвитку в здобувачів вищої освіти тонкого сприйняття типів, видів, особливостей композиції i колірної гармонії 
українського орнаменту, правил стилізації реальних форм у декоративні, особливостей компонування візерунка в смузі, колі, квадраті, трикутнику. Цей метод включав такі варіації: контрастної орнаментальної композиції; контрастного й гармонійного угруповання (розмір, форма, колір, розташування, зорова єдність); орнаментального контрапункту й простоти. Студенти на факультативних заняттях або майстер-класах, опановуючи побудову орнаментального контрапункту, створювали орнаментальні мотиви 3 низки замкнутих елементів шляхом з'єднання їх у цілісний орнаментальний образ. Здобувачі виконували стилізовані композиції із замкнутою структурою (штучні вироби) і композиції з відкритою структурою (тканини, килими смугові); ахроматичні (двотоновий: чорно-білі і сіро-білі; тритонові займають проміжне становище між двотоновими i кольоровими) i хроматичні (багатобарвні). Майбутні вчителі займалися складанням таких видів орнаменту: стрічковий, сітчастий, геометричний, рослинний, зооморфний, антропоморфний, каліграфічний. Вони створювали цілісний вигляд орнаменту з точок, прямих, звивистих ліній, кіл, ромбів, багатокутників, зірок, хрестів та ін. Ці елементи широко використовуються в декорі українських килимів, виробів ручного в'язання, різьби по дереву. Студенти, виконуючи умовно-символічні орнаменти, представляли їх у вигляді спіралі, як символу, що відганяє злих духів із житла; образних знаків-символів благополуччя й достатку; хвилястих ліній - знак родючості, трикутника - знак, що оберігає життя людини від негараздів, різноманітних хрестів - знаки, що зображують сонце, зірки, місяць тощо.

Відзначимо, у Донбаському державному педагогічному університеті на факультеті початкової, технологічної та професійної освіти в ході експерименту на факультативних практичних заняттях широко застосовувався метод музичнодекоративних варіацій, що дозволило провести паралелі між народною музикою й декоративно-ужитковим мистецтвом - i в художньому образі, i в окремих деталях. Музика використовувалася і як фон у роботі студентів, і як засіб, що забезпечує виконання, аналіз творчих робіт, як стимулювальний чинник задуму моделі власної роботи.

Продовжуючи висвітлення формувального етапу експерименту крізь призму застосовуваних методів навчання студентів практичних основ декоративно-ужиткового мистецтва, зауважимо таке. Використання методу ритмічного малюнка, при якому всі мотиви орнаменту розташовуються рівномірно за горизонтальними і вертикальними рядами, де у квадратному сегменті розміщується один або в ускладненому варіанті два мотиви, спрямовано на оволодіння студентами досвідом зображення смугового, хвилеподібного, 
картатого або зигзагоподібного ритмічного ладу. Майбутні вчителі створюють різні зразки картатого малюнка, який сприймається візуально досить чітко. Простим видом цього ритмічного ладу є шаховий, коли в сегменті розміщуються два або чотири мотиви, а складний вид - коли асиметричне розташування мотивів у сегменті створює складний малюнок.

Як показала експериментальна практична робота, використання методу аналізу декоративного орнаменту сприяло виробленню в студентів умінь виокремлювати окремі елементи візерунка, смислове значення символу, пояснювати витоки його виникнення й намічати можливі варіанти орнаментального задуму. Ми рекомендували здобувачам здійснювати аналіз за такими питаннями: завиток і його смислове значення; образ рослини, тварини i їх символічний зміст; фон і композиція рослинного орнаменту; образ народу в знаково-символічній системі орнаменту тощо.

Застосовуючи на майстер-класах або факультативних заняттях метод ігрового руху, студенти, імпровізуючи, через рух передавали елементи відносного спокою й руху в художніх образах декоративно-ужиткового мистецтва, статики і динаміки, пропорції і диспропорції, симетрії й асиметрії. Зазначимо, що всі орнаментальні композиції підрозділяються на статичні i динамічні. Статичні композиції (i орнаментальні мотиви) грунтуються на принципі асиметрії, неоднаковості, протиставлення. Студентам пропонувалося побудувати графічну композицію, у якій було б відображено пропорцію золотого перетину. Золотий перетин виходить при розподілі відрізка на дві нерівні частини таким чином, коли весь відрізок відноситься до більшої його частини, як більша до меншої. У мистецтві орнаменту золотий перетин використовується як контраст між двома величинами, що чітко фіксується людським оком, наприклад, простір і об'ємна форма характеризуються довжиною, шириною й висотою; напрям лінії може бути вертикальним, горизонтальним і похилим; людей за зростом поділяють на високих, низьких і середнього зросту, а за повнотою - на повних, худих і середньої повноти і т. п. Отже, студенти на заняттях із застосуванням методу ігрового руху використовували такі поняття, властиві декоративно-ужитковій творчості, як симетрія, асиметрія, пропорція, статика, динаміка, композиція та ін. у власній художній творчості зі створення орнаментальних зображень.

Метод проєктів орнаменту української вишивки, виробів місцевих майстрів сприяв оволодінню студентами досвідом регіональної декоративноужиткової творчості. На заняттях студенти експериментальних груп готували проєкт рослинного орнаменту із стилізованих зображень трав, листя, квітів, 
плодів, дерев за зразком виробів українського мистецтва, майстринь мистецтва художнього шиття, орнаменту: умовного, стилізованого, фантастичного (зображення птахів, звірів і тварин) за аналогами старовинних витворів мистецтва килимарства, різьблення по каменю і дереву, ліпного рельєфу. Вони проєктували антропоморфний орнамент за мотивами українських виробів побуту й начиння. Студенти створювали каліграфічний орнамент у творах вишивки, різьблення по дереву, художньої обробки кольорового металу, килимового мистецтва тощо з окремих букв, цифр, елементів тексту, виразних за своїм пластичним малюнком. Отже, ця група методів була спрямована на самостійне рішення студентами творчих завдань.

Формування вмінь - досить тривалий процес, що вимагає залучення студентів у різноманітну інтелектуальну творчу діяльність із залученням декоративно-ужиткового мистецтва. Важливо при цьому, щоб ця діяльність була продуктивною. Дослідно-експериментальна робота, проведена нами, показала доцільність організації продуктивної діяльності студентів педагогічного університету за допомогою зазначених вище методів.

Продовжуючи опис специфіки реалізації формувального етапу експерименту, зазначимо, що логіка практичних занять була орієнтована на розвиток у студентів досвіду самостійного відбору художнього матеріалу і пошуку народних, художніх і педагогічних цінностей у культурі свого народу. У процесі занять виховувалися художньо-естетичний смак, естетичний ідеал, уміння розуміти й відчувати красу навколишнього світу, почуття патріотизму й гордості за свій народ.

Дослідно-експериментальна робота показала, що основними способами, що стимулюють самостійну роботу студентів, були: конспектування, аналіз елементів декоративно-ужиткового мистецтва, порівняльний аналіз наукових напрямів у вивченні окремих видів народного мистецтва, аналіз аналогів традиційних та інноваційних підходів до розуміння ролі народної культури в суспільстві.

Практичні заняття факультативу «Народне декоративно-ужиткове мистецтво» були побудовані викладачами експериментальних ЗВО таким чином: груповий обмін думками про основні поняття засвоєного змісту, визначення загального поняття як предмета діалогу, порівняльний аналіз цінностей народу Донеччини / Полтавщини та України, відображених у творах народного мистецтва, самостійне визначення можливостей використання тих чи тих видів декоративно-ужиткового мистецтва і його цінностей у педагогічному процесі освітнього закладу. Ці заняття дозволили студентам набути досвіду ведення 
діалогу, дискусії, аналізу та обміну думками про погляди на народне мистецтво, що традиційно склалися.

Крім того, практичні знання складалися 3 освоєння технічними прийомами, художньо-виразними способами створення предметів народного мистецтва, пошуку індивідуальних творчих способів відтворення аналогів декоративно-ужиткового мистецтва.

Творчі практичні заняття були спрямовані також на розвиток здібностей студентів аналізувати видове різноманіття декоративно-ужиткового мистецтва (різьблення по дереву, кераміка, килимарство, в’язання, вишивка, художня обробка металу, розпис тощо), розвиток способів його проєктування в педагогічному процесі освітнього закладу та відтворення елементів декоративно-ужиткового мистецтва в ескізних замальовках. На цих заняттях здійснювалося формування ціннісного ставлення до мистецтва народу і власної гідності як людини - продовжувача духовного досвіду свого народу. Студентам особливо сподобалися практичні заняття, що проходили у вигляді художніх практикумів, рольових та імітаційних ігор. Вони мали таку логічну структуру: аналіз об'єкта декоративно-ужиткового мистецтва (образ, техніка, виразність), розподіл ролей (обов’язків, функцій, способів діяльності), колективна або індивідуальна реалізація задуму, рефлексивно-оцінна діяльність.

Теоретичній та практичній підготовці здобувачів вищої освіти сприяли також відвідування краєзнавчих музеїв та виїзди студентів у місця народних промислів (Музей народної архітектури, побуту та дитячої творчості в селі Прелєстне Слов’янського району Донецької області; Слов'янський краєзнавчий музей; Полтавський краєзнавчий музей імені Василя Кричевського; Полтавський районний музей рушника; Решетилівський музей ткацтва i вишивки; Решетилівська майстерня народних промислів; Національний музей-заповідник українського гончарства в Опішному та ін.). Мета цих виїздів полягала, з одного боку, у залученні до практичного досвіду з виготовлення виробів, а з іншого - до пізнання таємниць створення виразного образу і традицій жителів Донецької та Полтавської областей. Під час етноекскурсій і прогулянок зверталася особлива увага на красу природи як на джерело орнаментальних форм i мотивів, які використовують народні майстри в оздобленні своїх виробів; вивчалися окремі об’єкти народного мистецтва, їх форма, гармонія колірна і композиційна; здійснювалася проба технічних навичок, які теоретично були засвоєні на лекційних заняттях. Під час виїзних екскурсів студенти також опановували термінологією народного мистецтва, розглядали й апробували верстати i

Професіоналізм педагога: теоретичні й методичні аспекти. - Вип. 14 (Ч. 1). - Слов’янськ, 2021. 
пристосування, необхідні для створення виробів декоративно-ужиткового мистецтва.

На формувальному етапі експерименту в підготовці студентів до декоративно-ужиткової творчості широко використовувався потенціал позанавчальних закладів Донецької і Полтавської областей (Слов'янський міський палац дитячої та юнацької творчості; Донецький обласний палац дитячої та юнацької творчості; Полтавський міський палац дитячої та юнацької творчості, Полтавський обласний палац дитячої та юнацької творчості). Студенти залучалися до семінарів-практикумів («Сучасні підходи до естетичного виховання дітей засобами декоративно-ужиткового мистецтва» (Слов’янськ, 2018 р.), «Методика мотивації школярів до художньо-творчої діяльності» (Полтава, 2019 р.), «Народне декоративно-прикладне мистецтво одна із форм суспільної діяльності» (Слов’янськ, 2019 р.), «Розвиток творчих здібностей вихованців засобами художніх технік» (Полтава, 2020 р.), майстеркласів із художньої вишивки, випалювання по деревині, вишивки стрічками, бісероплетіння, макраме, образотворчого мистецтва, флористики, української народної іграшки, що проводили фахівці відділів образотворчого мистецтва та декоративно-ужиткової творчості цих установ.

Зауважимо, що, на думку студентів, майстер-класи були однією 3 найбільш ефективних форм щодо вдосконалення практичних умінь і навичок декоративноужиткової творчості. У них студенти можуть у невимушеній формі поспілкуватися $з$ майстром, який детально розкриває свою майстерність, показує технологію виготовлення виробів із різних матеріалів: глини, лози, дерева і т.п. Заняття підвищують інтерес студентів до художніх занять, розвивають творчість, стимулюють художню активність, самоосвіту.

Застосування різноманітних форм і методів навчання дозволило майбутнім педагогам оволодіти практичними вміннями декоративно-ужиткової творчості.

Дослідно-експериментальна робота в рамках цього дослідження передбачала поряд iз теоретичною i практичною підготовкою студентів педагогічного університету формування в них (як майбутніх учителів) відповідних методичних умінь, навичок у навчанні й вихованні молодого покоління засобами декоративно-ужиткового мистецтва.

Нами було окреслено такі вміння, які планувалося сформувати в студентів на формувальному етапі експерименту: керувати процесом освоєння учнями цінностями народного мистецтва, формування в них потреби в постійному пізнанні декоративно-ужиткового мистецтва; організувати педагогічний процес iз використанням можливостей декоративно-ужиткового мистецтва; вести 
Упровадження системи соціалізації студентської молоді педагогічного університету в позанавчальній діяльності засобами народного декоративно-ужиткового мистецтва

гурткову й факультативну роботу за видовою різноманітністю декоративноужиткової творчості.

Виходячи зі специфіки дослідження та орієнтуючись на теорію поетапного формування розумових дій (Севастьянова, 2005), нами були виділені такі етапи формування методичних умінь: а) початковий; б) основний; в) заключний.

Зауважимо, що методична підготовка студентів до роботи зі школярами на засадах декоративно-ужиткового мистецтва здійснювалася, в основному, у межах факультативних занять.

На початковому етапі формування методичних умінь у майбутніх учителів відбувалося попереднє ознайомлення 3 дією, тобто побудова у свідомості студентів орієнтовної основи дії, спрямованої на навчання й виховання школярів.

Оскільки у школі освоєння декоративної діяльності полягає в ознайомленні учнів із різноманітними матеріалами, 3 різними засобами художньої виразності творів декоративно-ужиткового мистецтва, то на початковому етапі майбутні вчителі знайомилися 3 методичними вміннями, необхідними для навчання школярів виділення засобів художньої виразності у творах декоративно-ужиткового мистецтва.

Причому, робився акцент в підготовці студентів факультету початкової, технологічної та професійної освіти на тому, що прояв того чи того засобу художньої виразності слід з учнями розглядати на багатьох прикладах з тим, щоб молодші школярі усвідомили всі їхні специфічні особливості перед подальшим практичним оволодінням декоративно-ужитковою творчістю.

На цьому етапі майбутні вчителі знайомилися 3 тим, як необхідно проводити бесіди щодо обговорення зі школярами творів декоративноужиткового мистецтва, розповіді про народну творчість. Крім того, студенти знайомилися з особливостями використання демонстраційного й ілюстративного матеріалу при навчанні школярів декоративно-ужиткової творчості. Вони за допомогою плакатів i таблиць освоювали техніку навчання школярів послідовного виконання творів декоративно-ужиткового мистецтва.

На основному етапі майбутні вчителі отримували i працювали 3 інформацією у вигляді різних матеріальних об’єктів: реальних предметів або їх моделей, схем, таблиць тощо, звіряючи свою дію з орієнтовною основою дії.

На цьому етапі студенти опановували вміння, необхідні для навчання школярів поетапного виготовлення творів декоративно-ужиткового мистецтва, вигадували творчі завдання, які сприяли формуванню в дітей умінь самостійно вибирати найоптимальніший художній матеріал або техніку для втілення свого

Професіоналізм педагога: теоретичні й методичні аспекти. - Вип. 14 (Ч. 1). - Слов’янськ, 2021. 
Упровадження системи соціалізації студентської молоді педагогічного університету в позанавчальній діяльності засобами народного декоративно-ужиткового мистецтва

задуму, наприклад, складання декоративних тематичних композицій: «Казкові птахи», «Весняні квіти на лузі» тощо.

Оскільки навчання дітей шкільного віку декоративно-прикладної творчості починається з копіювання зразків народних майстрів, то необхідно формувати в майбутніх учителів уміння організовувати навчання школярів виконання декоративних робіт на основі принципів народного мистецтва повтору й варіації. В основі першого принципу покладено повторення учнем зображення, що виконується вчителем. Другий принцип полягає в тому, що вчитель пропонує різні елементи декоративної творчості, а учень із них виконує різні композиційні варіації, наприклад, складання варіантів візерунків у смузі 3 геометричних елементів (коло, квадрат, трикутник).

Протягом заключного етапу студенти вдосконалювали вміння 3 навчання школярів народної творчості та вміння використання засоби декоративноужиткового мистецтва в навчанні та вихованні школярів. Грунтуючись на принципах повторення й варіації при навчанні школярів декоративно-ужиткової творчості, студенти автоматично виконували відпрацьовану дію, навіть подумки не контролюючи себе, чи правильно вона виконується. Це свідчило про те, що дія інтеріоризувалася, перейшла у внутрішній план, і необхідність у зовнішній опорі відпала. Застосування принципу імпровізації сприяло подальшому вдосконаленню методичних умінь студентів, необхідних для навчання й виховання школярів.

Висновки 3 дослідження і перспективи подальших розвідок у цьому напрямі. Отже, до процесу соціалізації студентської молоді педагогічного університету в позанавчальній діяльності засобами народного декоративноужиткового мистецтва доцільно активно залучати як суб'єктів адміністрацію 3ВО, викладачів, кураторів груп, керівників наукових гуртків, майстрів декоративно-ужиткового мистецтва, працівників позашкільних закладів, соціальних установ, закладів культури, представників місцевого самоврядування i громадських організацій. У подальшому для вивчення й наукового обгрунтування актуальними є розробка технологій використання декоративноужиткового мистецтва у вуличній роботі 3 населенням; наукових засад співробітництва державних, приватних і громадських структур в організації художньо-творчої діяльності дітей, молоді та осіб літнього віку.

\section{СПИСОК ВИКОРИСТАНИХ ДЖЕРЕЛ}

1. Бучківська, Г.В. (2019). Система професійної підготовки майбутніх учителів початкових класів на засадах народного декоративно-ужиткового мистецтва. (Дис. доктора пед. наук.). Тернопіль, Україна: Тернопільський нац. пед. ун-тім. Володимира Гнатюка.

() ДВНЗ «Донбаський державний педагогічний університет» 
Упровадження системи соціалізації студентської молоді педагогічного університету в позанавчальній діяльності засобами народного декоративно-ужиткового мистецтва

2. Власова, В.Г. (2019). Формування естетичного ставлення молодших школярів до навколишнього світу засобами образотворчого мистецтвв. (Дис. канд. пед. наук.). Київ, Україна: Інститут проблем виховання НАПН України.

3. Гарбузенко, Л.В. (2016). Формування художньо-естетичної компетентності майбутніх учителів образотворчого мистецтва у процесі вивчення декоративно-ужиткового мистецтвва. (Дис. канд. пед. наук.). Кіровоград, Україна: Кіровоградський держ. пед. ун-т ім. Володимира Винниченка.

4. Лавриненко, С.О. (2005). Підготовка майбутніх учителів початкових класів до національного виховання учнів засобами мистецтва. (Дис. канд. пед. наук.). Кіровоград, Україна: Кіровоградський держ. пед. ун-т ім. Володимира Винниченка.

5. Севастьянова, О.А. (2005). Позанавчальна діяльність у ВНЗ у контексті нової освітньої парадигми. Освіта Донбасу, 2, 70-73.

6. Сироткіна, Ж.С. (2006). Формування професійних умінь майбутніх учителів початкових класів засобами взаємодії різних видів мистецтвва. (Дис. канд. пед. наук.). Київ, Україна: Національний пед. ун-т ім. М. П. Драгоманова.

7. Тернопільська, В.І. (2003). Формування соиіальної відповідальності старшокласників у позанавчальній діяльності. (Дис. канд. пед. наук.). Житомир, Україна: Житомирський держ. пед. ун-т ім. Івана Франка.

\title{
IMPLEMENTATION OF THE STUDENT SOCIALIZATION SYSTEM OF THE PEDAGOGICAL UNIVERSITY IN EXTRACURRICULAR ACTIVITIES USING FOLK DECORATIVE-APPLIED ART
}

\author{
Svitlana Saiapina \\ Doctor of Pedagogical Sciences, Associate Professor, \\ Professor of the Department of Pedagogy of Higher School, \\ SHEI "Donbas State Pedagogical University", \\ Sloviansk, Ukraine \\ ORCID ID 0000-0001-5808-7020 \\ svetlana.sayapina65@gmail.com \\ Viktoriia Mukhina \\ Candidate of Pedagogical Sciences, \\ Senior Lecturer of the Department of General Psychology \\ SHEI "Donbas State Pedagogical University", \\ Sloviansk, Ukraine \\ ORCID ID 0000-0002-7248-672X \\ viktoriy.m3@gmail.com
}

\begin{abstract}
The current stage of development of independent Ukraine is characterized by a strategic course to renew all spheres of public life, including education. The success of the process of socialization of youth as a special demographic group is now determined as an important factor in the integration of institutions of education of Ukraine into the European educational space. That is why the priority tasks of the theory and practice of social pedagogy include substantiation of the importance of educational and cultural components in the general socialization process of a young person, creation, and implementation of favorable conditions for the educational environment.
\end{abstract}

Професіоналізм педагога: теоретичні й методичні аспекти. - Вип. 14 (Ч. 1). - Слов’янськ, 2021. 
Упровадження системи соціалізації студентської молоді педагогічного університету в позанавчальній діяльності засобами народного декоративно-ужиткового мистецтва

The problem of organizing non-academic or extracurricular work in the institution of higher education has been considered by such modern domestic scientists as A. Brusenko, S. Ivanchykova, O. Palekha, Ye. Pranova, I. Ratynska, S. Saiapina, V. Ternopilska, V. Tymoshenko, N. Shelest, etc.

The complex of works (Yu. Baranetska, H. Buchkivska, V. Vlasova, L. Harbuzenko, S. Lavrynenko, Zh. Syrotkina, V. Smikal, M. Tomashivska, I. Ushakova, L. Firsova, V. Chupina, V. Shvyrka, etc.) is devoted to the use of art as a means of personal development of a young person.

The purpose of the article is to highlight the specifics of the implementation of the system of socialization of student youth of the pedagogical university in extracurricular activities using folk decorative-applied art.

It is theoretically substantiated the system of socialization of student youth of the pedagogical university in extracurricular activities through folk decorative-applied art, which includes target, conceptual, subjective, content-technological, diagnostic-effective blocks; the characteristics of each of the system components are presented.

The effectiveness of the offered system of socialization of student youth of the pedagogical university in extracurricular activities through folk decorative-applied art and the feasibility of its implementation in the activity practice of pedagogical institutions of higher education are proved.

Thus, for the first time it has been developed, theoretically substantiated, and experimentally tested the system of socialization of student youth of pedagogical university in extracurricular activities using folk decorative and applied art, which includes target, conceptual, subjective, contenttechnological, diagnostic-effective blocks.

Key words: student youth; extracurricular activities; experiment; decorative and applied arts; socialization; Pedagogical University.

\section{REFERENCES}

1. Buchkivska, H.V. (2019). The system of professional training of future primary school teachers on the basis of folk decorative-applied art. (Doctoral dissertation). Ternopil, Ukraine: Ternopilskyi nats. ped. un-t im. Volodymyra Hnatiuka.

2. Vlasova, V.H. (2019). Formation of aesthetic attitude of junior schoolchildren to the world around them by means of fine arts. (PhD dissertation). Kyiv, Ukraine: Instytut problem vykhovannia NAPN Ukrainy.

3. Harbuzenko, L.V. (2016). Formation of artistic-aesthetic competence of future teachers of fine art in the process of studying decorative-applied arts. ( $\mathrm{PhD}$ dissertation). Kirovohrad, Ukraine: Kirovohradskyi derzh. ped. un-t im. Volodymyra Vynnychenka.

4. Lavrynenko, S.O. (2005). Preparation of future primary school teachers for the national education of pupils using art. (PhD dissertation). Kirovohrad, Ukraine: Kirovohradskyi derzh. ped. un-t im. Volodymyra Vynnychenka.

5. Sevastianova, O.A. (2005). Extracurricular activities in universities in the context of a new educational paradigm. Osvita Donbasu, 2, 70-73.

6. Syrotkina, Zh.Ye. (2006). Formation of professional skills of future primary school teachers using interaction of different types of art. (PhD dissertation). Kyiv, Ukraine: Natsionalnyi ped. un-t im. M. P. Drahomanova.

7. Ternopilska, V.I. (2003). Formation of social responsibility of high school pupils in extracurricular activities. (PhD dissertation). Zhytomyr, Ukraine: Zhytomyrskyi derzh. ped. un-t im. Ivana Franka.

Матеріали надійшли до редакції 05.04.2021 р. 